Diabetologia 10, $135-138$ (1974)

(C) by Springer-Verlag 1974

\title{
The Effect of a Glucose Load on Plasma Fatty Acids and Lipolysis in Adipose Tissue of Obese Diabetic and Non-Diabetic Patients
}

\author{
C.H. Gilbert, J. Kaye and D.J. Galton \\ Diabetes Research Laboratory, St. Bartholomew's Hospital, London, E.C.1., Fngland
}

Received: July 2, 1973, and in revised form: December 3, 1973

Summary. The release of fatty acids and glycerol from adipose tissue of obese diabetics and obese controls has been studied in relation to the fall in plasma fatty acids during a glucose tolerance test. Adipose tissue was taken at zero-time and $1 \mathrm{~h}$ after an oral glucose load $(50 \mathrm{~g})$. Obese diabetics released more fatty acids from adipose tissue than obese controls $(p<0.001)$, whereas glycerol release was similar in the two groups. The percent reduction in release of fatty acids from adipose tissue of obese diabetics during $a$ G.T.T. was significantly less than obese controls $(p<0.02)$, as was the percent fall in plasma fatty acids $(p<0.02)$, whereas the percent reduction in glycerol release from adipose tissue was similar in the two groups. In addition the percent fall in plasma fatty acids during a G.T.T. correlated with the percent reduction in release of fatty acids from adipose tissue $(p<0.05)$, but not with release of glycerol; and the increment in plasma insulin from zero-time to $1 \mathrm{~h}$ during a G.T.T. correlated with the percent reduction in fatty acid release from adjpose tissue $(p<0.01)$. Finally, the plasma insulin at $1 \mathrm{~h}$ of a G.T.T. correlated inversely with the release of fatty acids from adipose tissue $(p<0.05)$, but not with the release of glycerol. The data is consistent with the view that the plasma fatty acids fall during a G.T.T. due to re-esterification of fatty acids rather than due to an antilipolytic action of insulin.

Key words: Glucose tolerance, plasma fatty acids, plasma insulin, release of fatty acids, release of glycerol, adipose tissue, obesity, diabetes.
Plasma fatty acids fall precipitously during a glucose tolerance test and this decline is probably mediated by insulin [1]. However, insulin could produce this effect in either of two ways: by a direct antilipolytic action on adipose tissue, inhibiting the breakdown of triglycerides, or by stimulating the re-esterification of fatty acids in adipose tissue without altering the rate of lipolysis. A possible way to decide between these alternatives is to see if the lipolytic activity of adipose tissue measured in vitro correlates with the changes in plasma fatty acids and insulin that occur during a glucose tolerance test. We have measured. the decline in plasma fatty acids during an oral glucose tolerance test and obtained samples of adipose tissue at the start and at one hour after the glucose load in a group of obese diabetic and non-diabetic patients. The release of fatty acids and glycerol from the tissue has been examined for a correlation with the changes in plasma fatty acids and insulins during the first hour of the glucose tolerance test.

\section{Methods}

\section{Patients}

The following patients were included in this study: [1] six obese non-diabetic patients, mean age $36.3 \pm$ 6.3 years, mean height $162.5 \pm 1.8 \mathrm{~cm}$ and mean weight $91.8 \pm 1.8 \mathrm{~kg}$. The mean fasting blood sugar of this group was $69 \pm 3[6] \mathrm{mg} / 100 \mathrm{ml}$.

[2] six obese diabetic patients, mean age $47.3 \pm 4.6$ years, mean height $170.0 \pm 3.4 \mathrm{~cm}$ and mean weight
$86.7+7.4 \mathrm{~kg}$. The mean fasting blood sugar was 132 士 $22[6] \mathrm{mg} / 100 \mathrm{ml}$. All but one diabetic patient was more than $14 \%$ above ideal body weight according to tables from the Society of Actuaries [2]. The criterion for diagnosis of diabetes from blood sugar measurements was that of the College of General Practitioners [3]. Patients were admitted to hospital for an overnight fast and the first fat sample was taken the following morning prior to the administration of an oral glucose load $(50 \mathrm{~g})$. A second fat sample was taken after one hour, and blood samples were taken at thirty minute intervals throughout the test.

\section{Tissue Incubation}

Samples of adipose tissue were taken under local anaesthesia ( $1 \mathrm{ml}$ of lignocaine $1 \%$ ) by a needle biopsy technique, and the fat was transported to the laboratory in $0.9 \%$ saline. Tissue was preincubated for 10 min in an Earles' bicarbonate buffer $\left(\mathrm{Na}^{+} 143, \mathrm{~K}^{+}\right.$ 5.3, $\mathrm{Ca}^{2+} 1.8, \mathrm{Mg}^{2+} 0.8, \mathrm{Cl}-126$ and $\left.\mathrm{HCO}_{3}-25 \mathrm{~m} \mathrm{Eq} / \mathrm{l}\right)$ containing bovine erystalline albumin $(1 \% \mathrm{w} / \mathrm{v})$ under a gas phase of oxygen: $\mathrm{CO}_{2}$ (95:5). Approximately $200 \mathrm{mg}$ of adipose tissue was then incubated in $0.5 \mathrm{ml}$ of fresh albumin-bicarbonate buffer for one hour at $37^{\circ} \mathrm{C}$ in a shaking incubator. The medium was kept at $-10^{\circ} \mathrm{C}$ for assay of glycerol; and $0.4 \mathrm{ml}$ of the medium was extracted in Dole's solution for assay of free fatty acids.

\section{Measurements}

Glycerol was measured in $50 \mu \mathrm{l}$ aliquots of the incubation medium using the enzymatic method of Garland and Randle [4]. The change in optical density was 
measured in a Unicam SP 800A recording spectrophotometer with scale expansion accessory. Free fatty acids were measured using the semiautomated procedure of Carruthers [5], in which the plasma is extracted by the procedure of Dole with an additional wash of the apolar phase with phosphate buffer $(67 \mathrm{mM}$ p.H. 7.0) to remove phospholipids and low molecular weight fatty acids which interfere. The extracted fatty acids are measured in a Technicon Autoanalyser by their ability to quench an ethanolic solution of fluorescein. Palmitic acid dissolved in $\mathrm{n}$-heptane was used as standard. Insulin was measured in duplicate by a standard radioimmunoassay, using dextran-coated charcoal as the separating agent [6].
During the first hour of the oral glucose tolerance test there was a decline in plasma fatty acids and a parallel decline in tissue release of both fatty acids and glycerol, which was more marked in the non-diabetic patients (Table 2). However the ratio of fatty acid to glycerol output by the tissue remained the same during the first hour of the tolerance test, although the ratio was greater in the diabetic group $(5.1 \pm 0.52(12))$ compared with the non-diabetic group $(2.62 \pm 0.54(12)$ $p<0.01$ versus diabetics).

Fig. 2 presents a time course for one of the obese patients and shows the changes in plasma fatty acids, blood glucose and tissue release of fatty acids and glycerol that occurred. The percent fall in plasma fatty

Table 1. The release of glycerol and fatty acids from adipose tissue in vitro

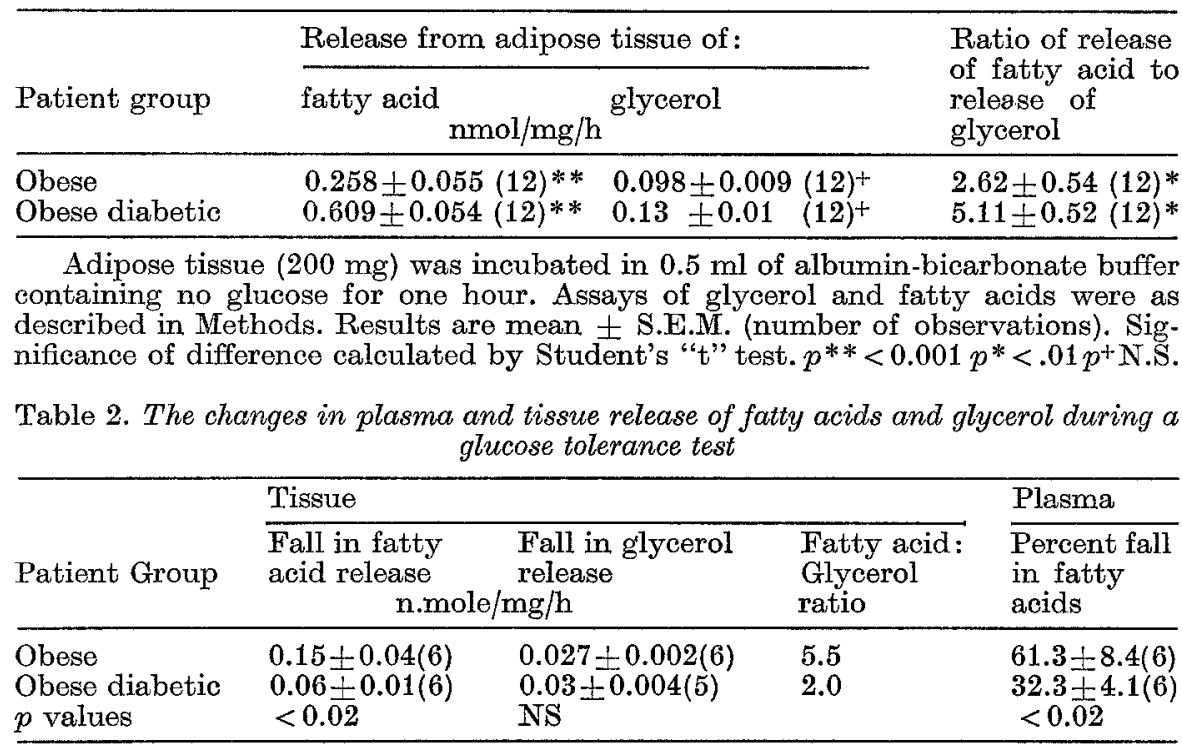

Results are means \pm SEM (number of observations); significance of differences tested by Student's " $t$ ".

Statistics: Regression analysis was performed by the method of least squares and correlation coefficients were calculated by the product-moment method. Significance of mean differences and correlation coeffi. cients were tested using Student's " $t$ " distribution.

\section{Results}

The results of the release of fatty acids and glycerol from adipose tissue of the patients in this study are presented in Table 1. Although adipose tissue from diabetics released more fatty acids into the medium than that from non-diabetics, the release of glycerol by the two groups was similar. Furthermore, the plasma level of fatty acids at one hour after a ghucose load significantly correlated with the tissue output of fatty acids $(\mathrm{r}=0.67, \mathrm{n}=11, p<05)$, and also with the release of glycerol $(\mathrm{r}=0.67, \mathrm{n}=11, p=<0.05$ into the incubation medium (Fig. 1)).

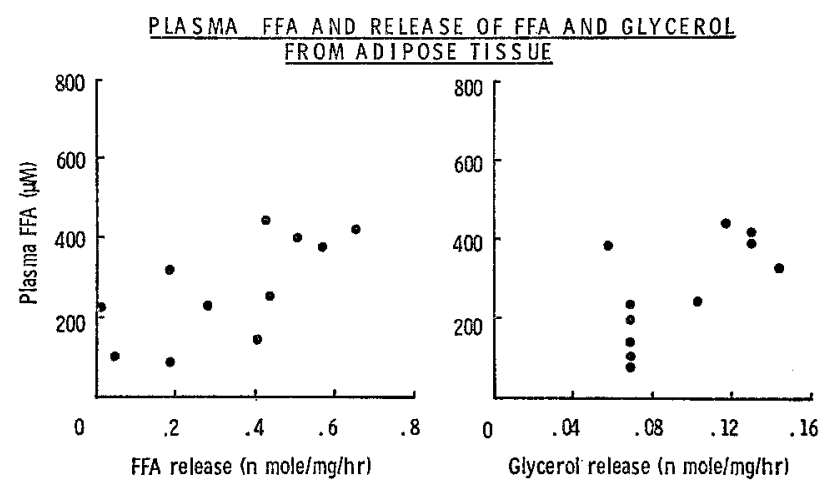

Fig. 1. Release of fatty acids and glycerol from adipose tissue related to levels of plasma fatty acids. Blood and adipose tissue was taken at one hour from the start of a glucose tolerance test and the plasma fatty acids, tissue release of fatty acids and glycerol was measured according to Methods. Points are individual patients described in Methods. For plasma fatty acids versus tissue rolease of fatty acids $\mathrm{r}=0.67, \mathrm{n}=11, p<0.05$, for plasma fatty acids versus glycerol release $\mathbf{r}=0.67, \mathrm{n}=11, p<0.05$ 
acids correlates significantly with the percent fall in tissue release of fatty acids (Fig. 3. $\mathrm{r}=0.67, \mathrm{n}=12$, $p<0.05$ ), but not with the percent fall in release of glycerol ( $\mathrm{r}=-0.09, \mathrm{n}=11, \mathrm{p}$. N.S.).

The effects on plasma fatty acids and tissue release of fatty acids and glycerol during a glucose tolerance test could be mediated by insulin. The increment in plasma insulin during the first hour of the test was

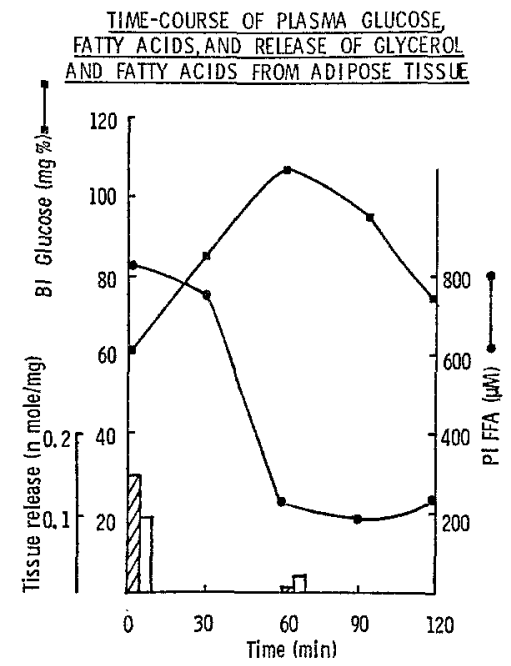

Fig. 2. Time course of plasma glucose, fatty acids and release of glycerol and fatty acids from adipose tissue in an obese patient

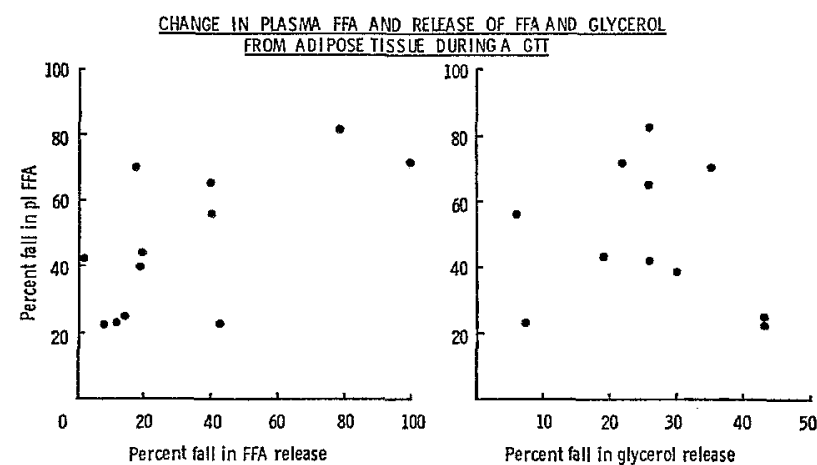

Fig. 3. The change in plasma fatty acids and release of fatty acids and glycerol from adipose tissue during a glucose tolerance test. Blood and adipose tissue were taken at zero-time and at $1 \mathrm{~h}$ after a glucose load. The percent fall in plasma fatty acids is related to the percent fall in tissue release of glycerol and fatty acids. For plasma fatty acids versus tissue release of fatty acids $\mathrm{r}=0.67, \mathrm{n}=12, p<0.05$. For plasma fatty acids versus release of glycerol $\mathrm{r}=-0.09, \mathrm{n}=11$, p.N.S.

found to correlate significantly with the percent decline in tissue release of fatty acids (Fig. $4 . r=0.79, n=10$, $p<0.01$ ); and the plasma levels of insulin at one hour after glucose correlated with the release of fatty acid by the tissue at one hour $(\mathrm{r}=-0.61, \mathrm{n}=10, p<0.05)$, but not with glycerol release at this time $(r=-0.17)$ $\mathrm{n}=10$, p. N.S.), as shown in Fig. 5 .

\section{Discussion}

The plasma levels of fatty acids under defined nutritional conditions correlate significantly with the release of fatty acids from adipose tissue incubated in vitro. Also, during a glucose tolerance test the decline in plasma fatty acids correlates significantly with the changes in output of fatty acids from adipose tissue in

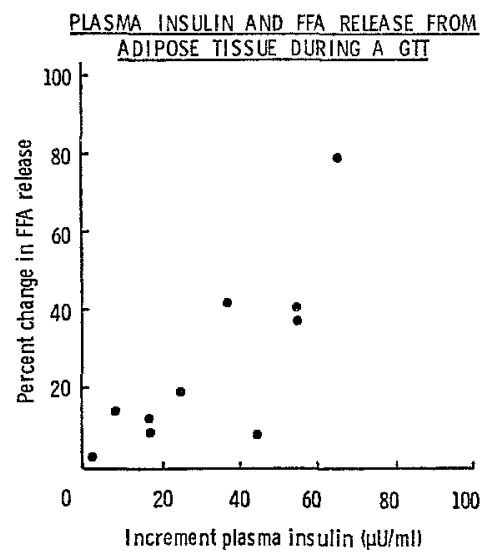

Fig. 4. The change in plasma insulin and change in tissue release of fatty acids during a glucose tolerance test. Blood and adipose tissue were taken at zero-time and at $1 \mathrm{~h}$ after a glucose load. The increment in plasma insulin is related to the percent fall in release of fatty acids from adipose tissue. Points are individual patients and $\mathrm{r}=0.79, \mathrm{n}=10, p<0.01$

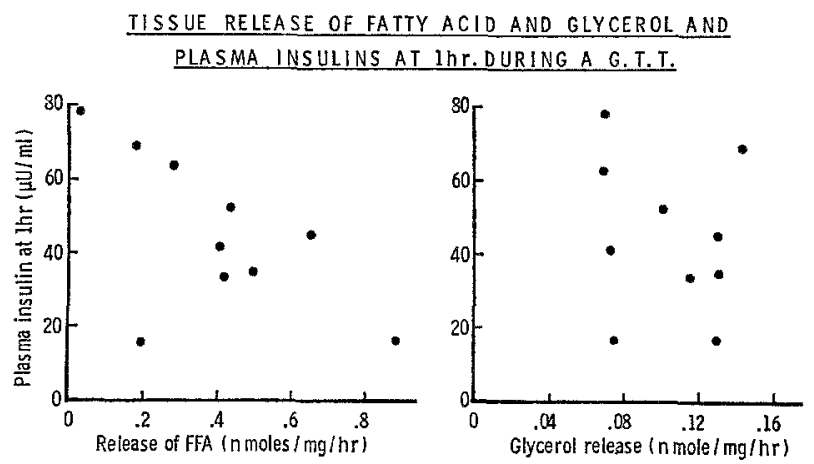

Fig. 5. The tissue release of fatty acids and glycerol related to plasma insulins at one hour during a glucose tolerance test. Blood and adipose tissue were taken at one hour after a glucose load, and the plasma insulins are related to the tissue output of fatty acids and glycerol. For plasma insulin versus tissue release of fatty acids $\mathbf{r}=-0.61, \mathrm{n}=10, p<0.05$. For plasma insulin versus glycerol release $\mathrm{r}=-0.17, \mathrm{n}=10, \mathrm{p} . \mathrm{N}$.S.

vitro. This suggests that the metabolic activity of adipose tissue in vitro may continue to reflect the immediate physiological situations from which it was removed; and also that the metabolic activity of the tissue undergoes rapid changes in vivo and that such changes persist under in vitro conditions despite a greatly simplified hormonal and ionic environment. 
The output of fatty acids by adipose tissue of adult diabetics is greater than non-diabetics, confirming other results [7], but since the release of glycerol was similar in the two groups this may indicate a decreased rate of re-esterification of fatty acids in diabetics rather than an increased rate of lipolysis. During a glucose tolerance test plasma fatty acids fell to a greater extent in the non-diabetics than the diabetics [8] and this is associated with the parallel changes in the release of fatty acids from adipose tissue in vitro. In the diabetic, therefore, there may be either an impaired rate of reesterification of fatty acids during the first hour of the glucose tolerance test or an impaired antilipolytic action on adipose tissue. Insulin is known to exert a direct antilipolytic action on human adipose tissue [9], which is best observed in tissue incubated with catecholamines in the absence of glucose. Insulin reduces the release of fatty acids and glycerol from the tissue as well as lowering intracellular levels of cyclic AMP [10]. The fact that there is a significant correlation between the increment in plasma insulin and the decrement in release of fatty acids from adipose tissue in vitro does suggest that insulin is involved in the decline in plasma fatty acids, but does not indicate which action of insulin is operative. However plasma levels of insulin correlate with the release of fatty acids from adipose tissue at one hour but not with the release of glycerol. This suggests that the effect of insulin is more by stimulating the re-esterification of fatty acids than by its direct antilipolytie action. This is in keeping with other data showing that during an insulin tolerance test no changes are detected in levels of cyclic AMP in freeze clamped pieces of adipose tissue taken at 0,15 and $30 \mathrm{~min}$ after injection of insulin [10].

\section{References}

1. Dole, V.P.: A relation between non-esterified fatty acids in plasma and the metabolism of glucose. J. clin. Invest. 35, 150-154 (1956)

2. Jelliffe, D.B.: The assessment of the nutritional state of the community, p. 238-241. Geneva: W.H.O. publication

3. The college of general practitioners, report of a working party. Brit. med. J. 1962 I, 1497-1503

4. Garland, P.B., Randle, P.J.: A rapid enzymatic assay for glycerol. Nature (Lond.) 196, 987-988 (1962)

5. Carruthers, M.: Automation in clinical chemistry. (Ed. Skeggs L.T.) (in press)

6. Herbert, V., Lau, K.S., Gottlieb, C.W., Bleicher, S.J.: Coated charcoal immunoassay of insulin. J. elin. Endocr. 25, 1375-1384 (1965)

7. Carlson, L.A., Östman, J.: In vitro studies on the glucose uptake and fatty acid metabolism of human adipose tissue in diabetes mellitus. Acta. med. scand. 174, 215-218 (1963)

8. Hales, C.N., Randle, P.J.: Effects of low-carbohydrate diet and diabetes mellitus on plasma concentration of glucose, non-esterified fatty and insulin during oral glucose tolerance tests. Lancet 1963 I, 790-794

9. Burns, T.W., Langley, P.E.: Observations on lipolysis with isolated adipose tissue cells. J. Lab. clin. Med. 72, 813-823 (1968)

10. Gilbert, C.H., Kaye, J., Galton, D.J.: The effect of catecholamines and fasting on cyclic-AMP and release of glycerol from human adipose tissue (in preparation)

Dr. D.J. Galton

Diabetes Research Laboratory

St. Bartholomew's Hospital

London EC 1A 7BE

England 